\title{
Correction to: A Model of the Optimal Tax Mix Including Capital Taxation
}

\section{John Revesz ${ }^{1}$ (D)}

Published online: 24 September 2020

(C) International Atlantic Economic Society 2020

\section{Correction to: Atl Econ J \\ https://doi.org/10.1007/s11293-020-09676-0}

The initial online publication contained several typesetting errors. The original article has been corrected.

Publisher's Note Springer Nature remains neutral with regard to jurisdictional claims in published maps and institutional affiliations.

The online version of the original article can be found at https://doi.org/10.1007/s11293-020-09676-0

John Revesz

john.revesz2@upcmail.hu

1 Australian Public Service, Canberra, Australia 